\title{
Knowledge management: uncovering risky gaps underlying the criticisms and moving to another perspective
}

\author{
Patricia Nascimento Souto \\ Pós-graduação em marketing (ESPM-SP). \\ Mestre em ciências da comunicação (USP). \\ Mestre de estudos de pesquisa integrada. \\ Phd em information estudos - em andamento - \\ Universidade de Tampera (Finlândia). \\ E-mail: patriciacnascimento@gmail.com
}

\begin{abstract}
The comments related to the sustainability of knowledge management (KM) have shown signs that it possibly can be a discourse which determines a quick style, but otherwise have also allowed the building of a better understanding about the limits and weaknesses of the knowlege management. In addition to the criticisms, the conceptual bases of knowledge management have been undermined by a contradictory combination of paradigms; there are also contradictions between the theoretical perspective jubjacent to the knwoledge management and its operationality. As a way of minimizing the possibility that the knowledge management may be turned into an umbrella concept and fail, it is suggested that its approaches embody a more interpretative perspective, taking up the role of an instrument which enables and facilitates the processes and practices in building up knowledge and information, enhancing their focus on the support to the establishment of human competences in order to deal intelligently with the present overcharge of information resources and need for building up information in the organizations.
\end{abstract}

\section{Keywords}

Knowledge management. Information management. KM. Criticisms. Knowing. Fad. Fashion.

\section{Gestão do conhecimento: revelação das lacunas perigosas que servem de base para a crítica e levam a outra perspectiva}

\section{Resumo}

Os criticismos relacionados à sustentabilidade da gestão do conhecimento (KM) têm evidenciado sinais que possivelmente ela seja um discurso determinador de uma moda passageira,mas em contrapartida também têm possibilitado a construção de melhor entendimento sobre as limitações e fraquezas da gestão do conhecimento. Além dos criticismos, os fundamentos conceituais da gestão do conhecimento têm sido minados por uma combinação contraditória de paradigmas; há também contradições entre a perspectiva teórica subjacente à gestão do conhecimento e a sua operacionalização. Como uma forma de minimizar a possibilidade de a gestão do conhecimento se tornar um conceito "guarda-chuva" e entrar em colapso, sugere-se que suas abordagens incorporem uma perspectiva mais interpretivista, movimentem-se mais na direção de ser um instrumento capacitador e facilitador dos processos e práticas de construção de conhecimento e de informação, e fortaleçam seu foco no suporte à criação de competências humanas para lidar inteligentemente com a atual sobrecarga de recursos informacionais e de necessidade de construção de informação nas organizações.

\section{Palavras-chave}

Gestão do conhecimento. Construção de conhecimento. Criação de conhecimento. Gestão da informação. Construção de informação. Criação de informação. KM. Criticismo. Moda.

\section{THE CRITICISMS DIMENSIONS AND ELEMENTS}

The criticisms about the sustainability of knowledge management (KM) have evidenced clues to a fashionsetting possible discourse and consequently, they have also helped to get a better understanding of KM limitations and weaknesses. Although these clues lead to a KM rethinking, they do not exhaust every possibility of KM being a fashion, since there are other critical and risky KM gaps that can undermine KM conceptual and practical sustainability.

The criticisms have linked KM to just another managerial fashion, which can be conceptualized as strong temporally discourses and changes associated to it (BENDERS and VEEN, 2001, p.40). A fashion can be identified by the use or occurrence of the following elements: the promise to provide heavy enhancement on performance; the risk of disaster if the concept is not adopted; the use of best practices from successful and well-known users; the broad applicability of the concept; the concept presentation as easily understandable, innovative, well-timed and oriented to the future; and the existence of space for multiple interpretations (BENDERS and VEEN, 2001, p. 35-40).

Having the concept and the defining features of a management fashion in mind; the criticisms of KM sustainability were analysed and they can be presented in three main interconnected dimensions: (1) conceptual; (2) strategic and (3) operational.

In the first place, the criticisms concerned with the conceptual dimension of $\mathrm{KM}$ have been calling attention to the broadness or vagueness of $\mathrm{KM}$ concept, to the KM semantic ambiguity and simplicity; to the positioning as the 'antidote' or 'successor' for failed approaches; and to the unclear distinction between the KM and the Information Management (IM) fields. Within this dimension of the criticisms, attention is called mainly to the effects of the broadness of KM meaning (i.e., the encompassment of a broad variety of phenomena) and the loose use of it. Alvesson and Karreman (2001, p.997) have 
indicated that the study about the use of the term KM in the literature has shown that it means more to knowledge than to management. Thereby, the KM idea has been built up on a vague and broad concept of knowledge, and so, has weakened itself.

Linked with the criticized broadness aspect, the semantic ambiguity of KM has also been discussed and emphasized by the volume of work that declares itself as providing definitions of the KM concept. The unclearness of KM meaning promotes personal translations (BENDERS; VEEN, 2001, pp. 36-38), indicating that $\mathrm{KM}$ discourse can be a fashion (SCARBROUGH; SWAN, 2001, pp. 3, 8).

In addition to the KM ambiguity, the criticisms about the simplicity of its concept have been identified when $\mathrm{KM}$ is presented as a unique or as the best solution for all problems. Simplicity was reported as being elevated when emphasis is given to the IT as the $\mathrm{KM}$ enabler (SCARBROUGH; SWAN, 2001, p. 3, 8-9), and when $\mathrm{KM}$ results are stated as being achievable by a single, fragmented and tactical maneuver (e.g., repositories, intranet or systems).

Equally addressed were the criticisms about the KM positioning as the 'antidote' or 'the substitute of precedent failed concepts. This positioning was connected to the fact that the management concepts discourses do not feed or even cross-reference each other, but instead, they compete on ideas. This absence of learning moving among approaches is explained by the commercial exploitation interests (SCARBROUGH; SWAN, 2001, p.9).

Moreover, the criticisms related to the unclear distinction between the meanings of $\mathrm{KM}$ and Information Management (IM) have been discussed by Wilson (2002), Al-Hawamdeh (2002), Kakabadse et al. (2001), Tsoukas and Vladimirou (2001, p.974), Martensson (2000, p. 208) and Streatfield and Wilson (1999). According to the authors, what is really managed is the information about knowledge, not the knowledge itself; since knowledge is what someone knows, and it involves comprehension, understanding and learning process on the mind of an individual. So, the individual expression of what is known and the messages created do not have or transmit knowledge, but only information about knowledge.

The KM criticisms on the strategic dimension have been related to the manageability of knowledge; to the 'must do' discourse of KM; and to the KM presentation as a radical rupture from existent ideas. The manageability of knowledge was discussed by Kakabadse et al. (2003) and Metaxiotis et al. $(2005$, p. 13) who doubted what in fact has been managed, since knowledge is speedily being created, destroyed, recreated and changed. It is worth pointing out that Metaxiotis et al. (2005), Kakabadse (2003), Wilson (2002) and Sveiby declared that knowledge itself can not be managed, since it is personal, subjective and resides on an individual's mind.

Still in the strategic dimension of criticisms, the 'must do' discourse of KM has been identified by the positioning of $\mathrm{KM}$ as the unique approach or as an imperative tool in order to prevent failure or disaster. The criticisms about the presentation of $\mathrm{KM}$ as a radical rupture from existent ideas were also identified in the literature (See SCARBROUGH; SWAN, 2001, p. 9).

Finally, criticisms within the operational dimension of $\mathrm{KM}$ refer primarily to the promises made linking the use of information technologies (IT) as the most important KM strategy.

All the criticisms outlined above have presented the KM management fashion characteristics and so, have revealed the likelihood of $\mathrm{KM}$ being labeled as a fashion. Most of these characteristics could be attributed to the interests of the commercial exploitation of KM (ALVESSON; KARREMAN, 2001, p.1015, SCARBROUGH; SWAN, 2001, p. 9). On top of that, the criticisms have brought to view the complex challenges that KM still needs to overcome: the agreement over the definitions, methods and practices and the overcoming of the approach fragmentation. But, what is still missing in the fashion-setting judgments is the point of view of the adopters and users of $\mathrm{KM}$ and also a deeper understanding of the problems on the KM conceptual foundation.

\section{THE CRITICISMS: CONTRIBUTIONS AND MISSING POINTS}

The criticisms are a partial judgment since they have focused solely on the diffusion of this fashion or on the suppliers actions (e.g., the fashion-setters like 'gurus', consultants, technology vendors and academics) (SCARBROUGH et al., 2005, p.198, SCARBROUGH; SWAN, 2001, p.11, ABRAHAMSON; ROSENKOPF, 1997); they have treated the adoption of $\mathrm{KM}$ as a process apart from implementation (i.e., KM users) and apart from the institutional contexts (WILLIAM, 2004, p. 775). 


\section{FIGURE}

$\mathrm{KM}$ behavior accordingly to article counts in the period 1991-2001 (Koenig, 2004, p. 37).

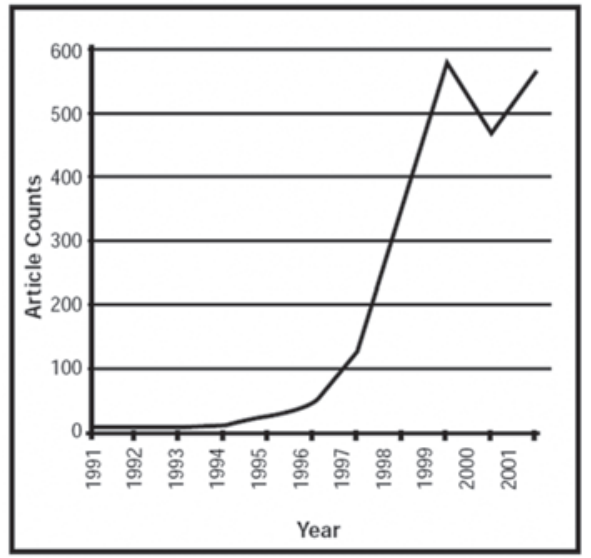

Even if the fashion-setting analysis limits itself only to the KM settlers' actions and to the number or articles in the literature (i.e., as it was performed by some authors like KOENIG, 2004, MILLER et al., 2004, ABRAHAMSON, 1996, ABRAHAMSON; FAIRCHILD, 1999 and PONZI; KOENIG, 2002); it can be seen that KM has not shown a behavior (Fig. 1) like other management fads* (Fig. 2).

Additionally to the bibliometric analyses generally done, the adopters and users of KM should be considered because they are not passive actors. The inclusion of the active function of the various groups involved emphasize their influence as the potential sources of legitimacy, and their key role in arbitrating either the demand or the consumption of fashions (SCARBROUGH et al., 2005, p. 199, SCARBROUGH; SWAN, 2001). Given that, the findings of research made by The KMPG Consulting $(2000)^{* *}$, demonstrated KM importance and critical role; the position of $\mathrm{KM}$ on the top of business agenda of several organizations; and also demonstrated the insignificant gap (20\%) between the expected and realized benefits (Figs. 3, 4 and 5).

\footnotetext{
* In general, management fashions have 5 years of explosive growth and 5 or 6 years of almost dramatic decline.

"* This research was done with 423 organisations in the UK, Europe and the USA. The concepts adopted for this were: Knowledge was considered as the knowledge in the business about customers, products, processes, competitors, etc. that can be locked away in people's minds or electronic form Knowledge Management:: considered as the systematic and organised attempt to use knowledge within an organisation to improve performance (KPMG, 2000, p.6)
}

FIGURE 2

Lifecycles of some management fads (1991. 2001): Quality Circles (1977-1986), Total Quality Management (1990-2001) and Business Process Reengineering (1990-2001) (Koenig, 2004, p.37)

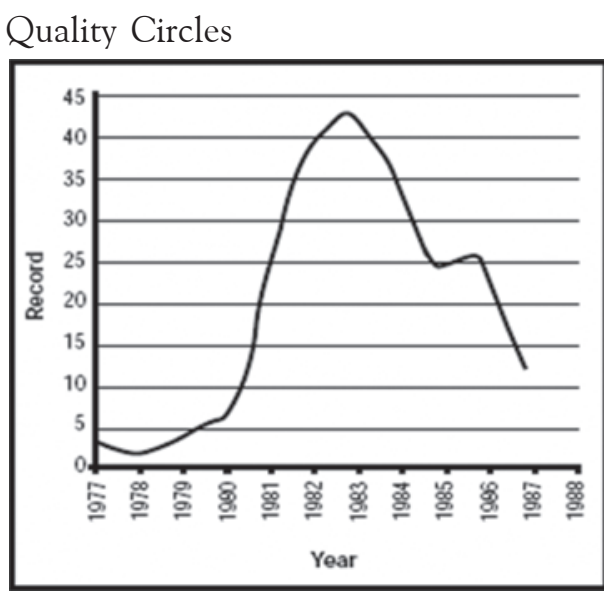

Total Quality Management Reengineering

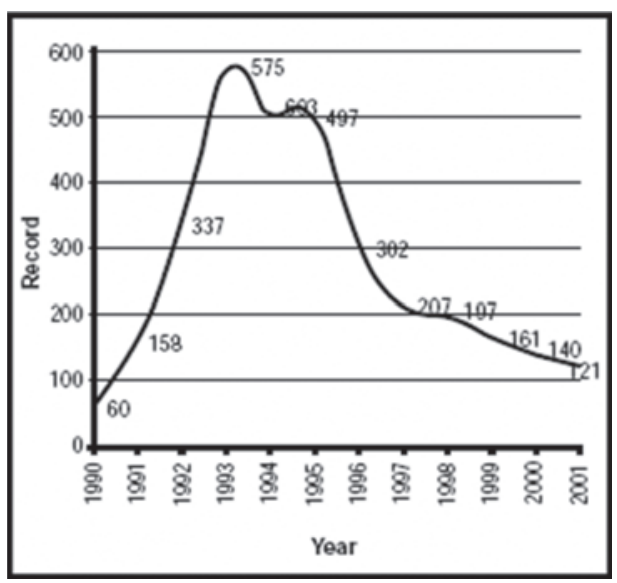

Business Process

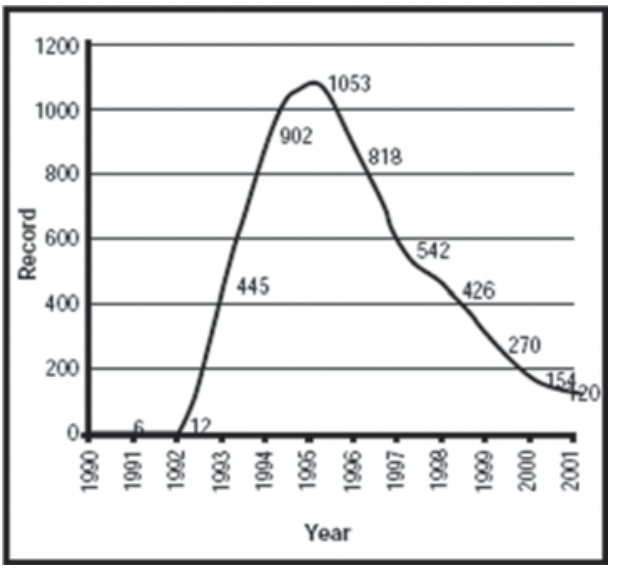


FIGURE 3

Respondents were asked whether their organisation had a KM strategy (KPMG, 2000, p.7).

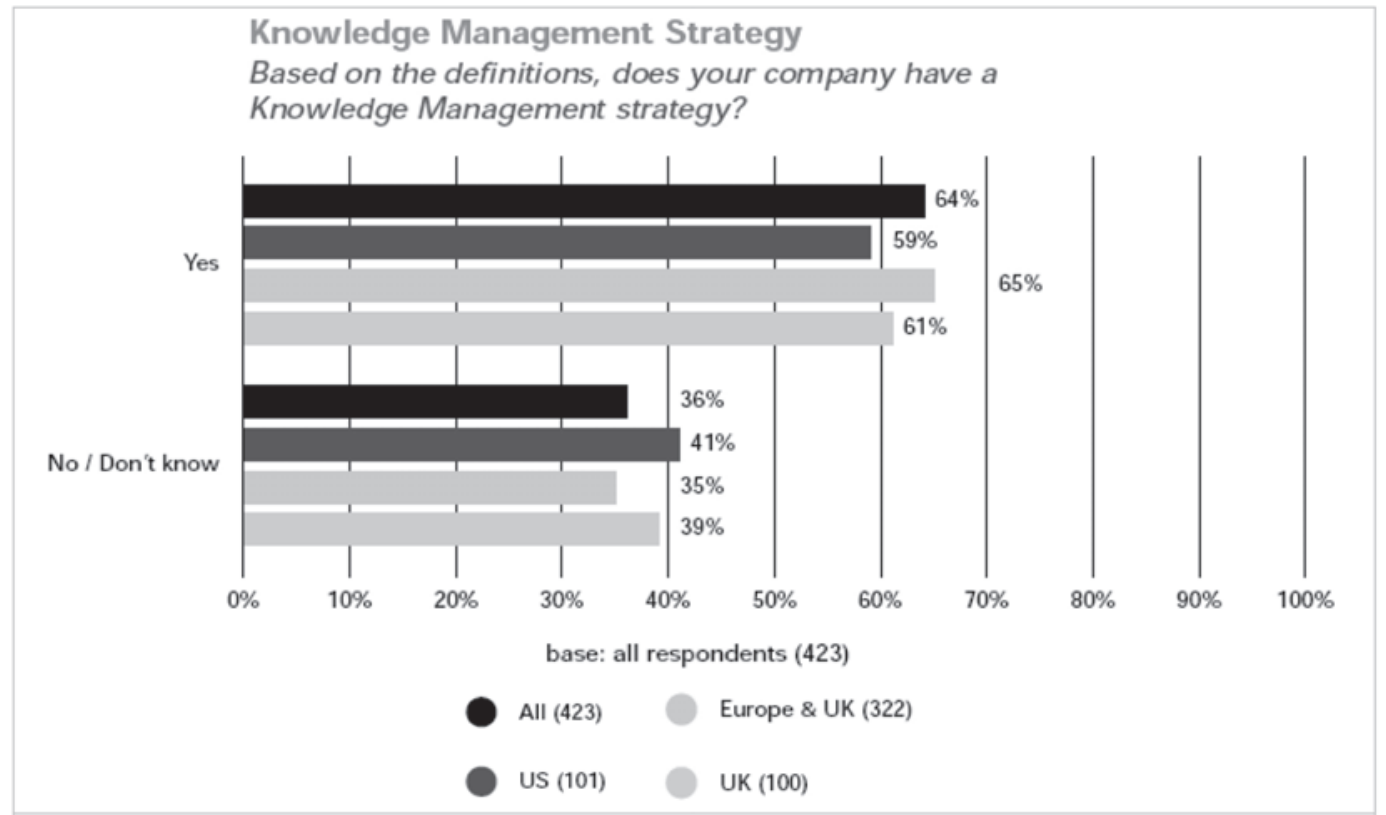

FIGURE 4

Respondents were asked to specify the extent of their organisation's KM Programme (KPMG, 2000, p.7-8).

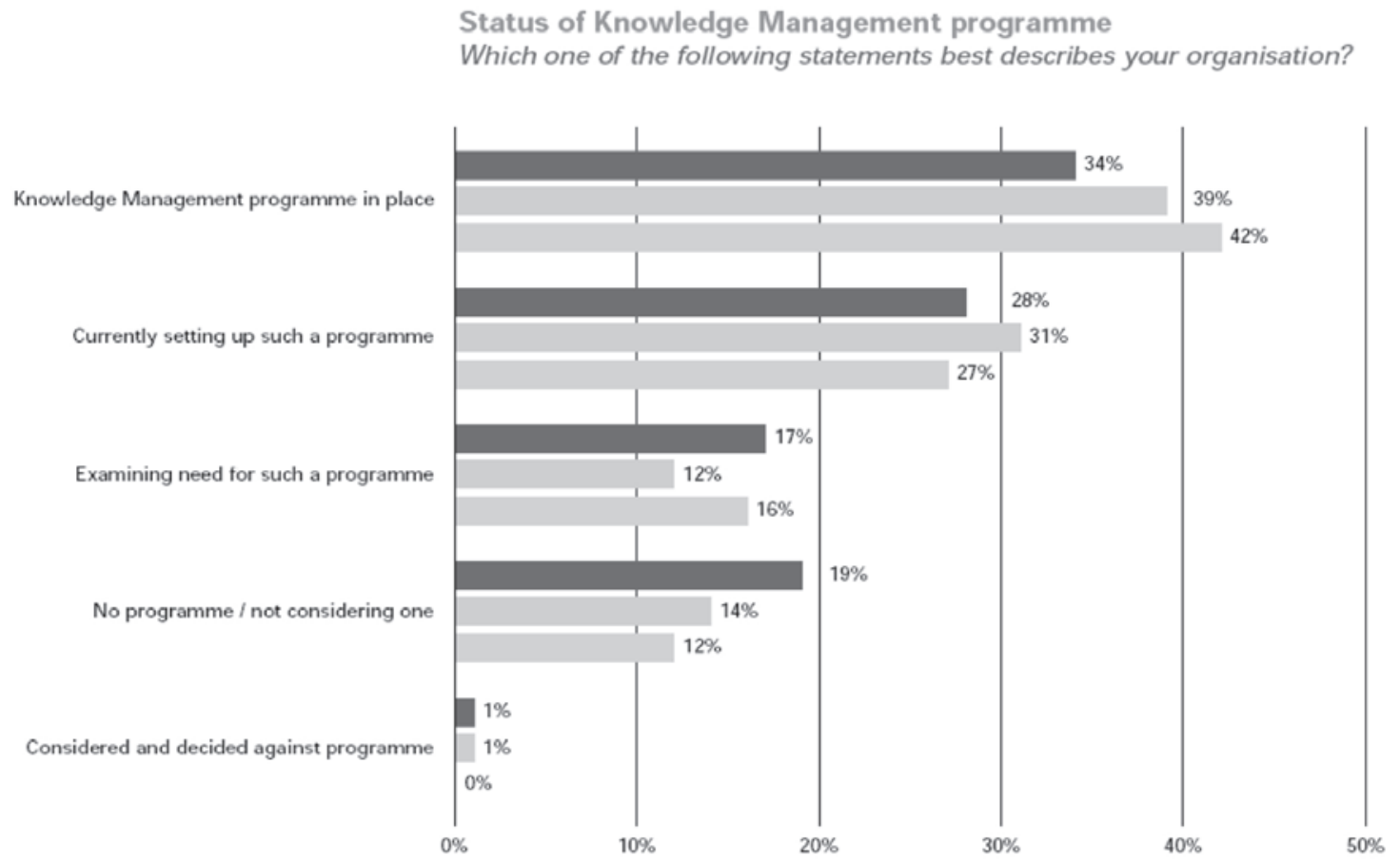


FIGURE 5

Respondents whose organisations had a KM programme in place were asked to identify the benefits they had realized from KM (KPMG, 2000, p.14).

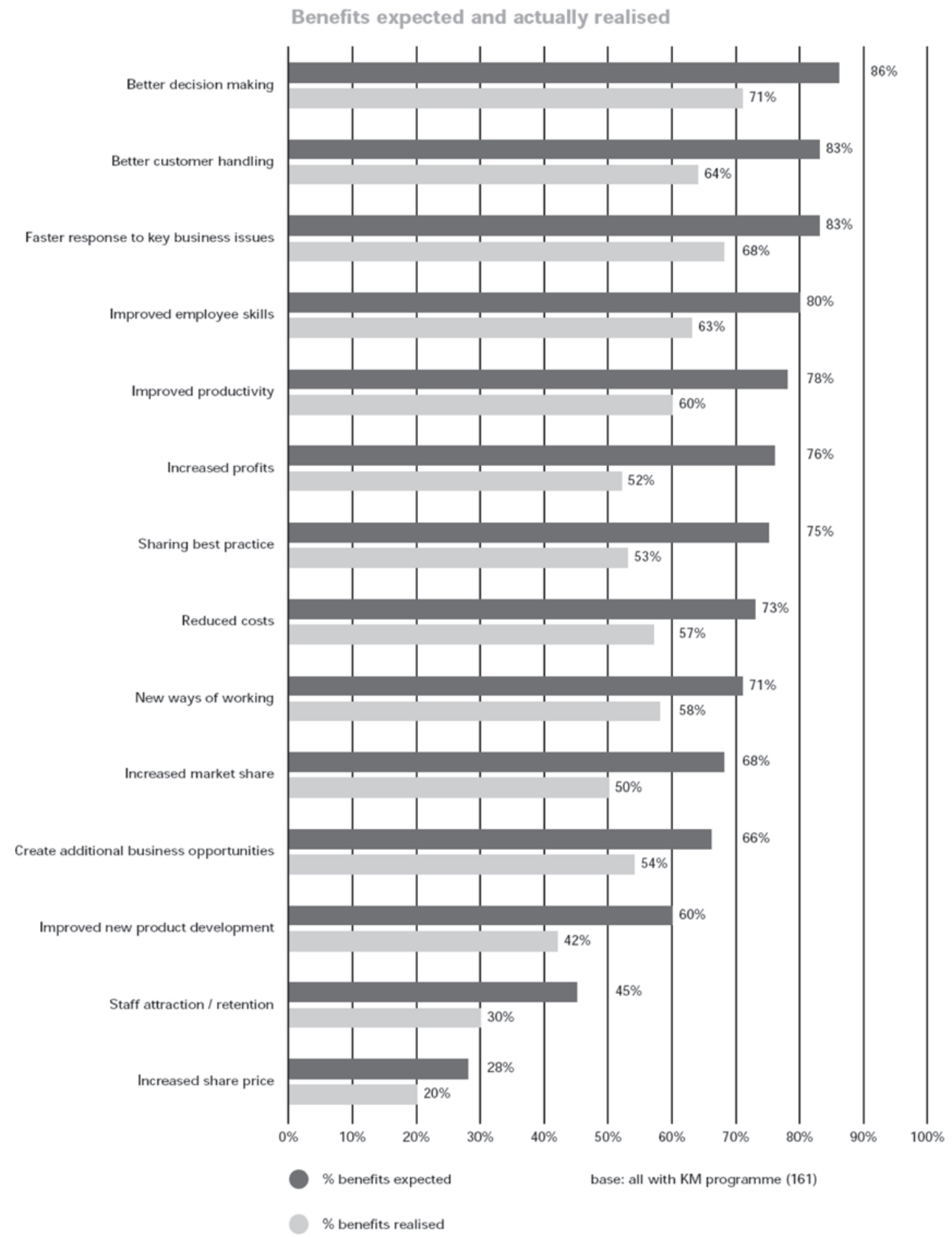


The bibliometric analysis of KM and the consideration of the results of projects have shown that KM is not a fashion. Although very positive, these evidences do not exhaust the fashion-setting probability of KM, because the KM conceptual foundations have being undermining it by a contradictory combination of paradigms. This is resulting in more critical gaps, overlaps, unclearness; and strategic misleading that can reinforce the KM likelihood to be just a new label.

\section{BEYOND CRITICISMS: UNDERLYING, UNDERMINING AND RISKY GAPS}

Central to the questions brought to view by KM criticism, is the main contradiction found in the KM literature: $\mathrm{KM}$ results are required based on an interpretivist understanding of knowledge (i.e., where the social and human nature are emphasized), but conversely, $\mathrm{KM}$ is made operative by a functionalist perspective (i.e., which is embedded in its concepts, practices, methods and tools). As a consequence of the dominance of the functionalist paradigm, many of the KM elements, devices, directions, formulas and models were found to be more mechanistic, covering only specific views of $\mathrm{KM}$ and neglecting questions as context influences (SCARBROUGH; SWAN, 2001, p. 4, MCADAM; MCCREEDY, 2000, p. 156). The KM understanding has been based more on a functionalist paradigm than on a more interpretivist one* (JASHAPARA, 2004, pp. 42, 44, ALVESSON; KARREMAN, 2001, p.999). At root, the dominant notion of knowledge is positivistic and of learning is “simplistically mechanical” (SPENDER, 1996, p.64).

The functionalist paradigm views knowledge as an object that exists separately of human acts and awareness; that can be owned, acquired and distributed; and has the role of reducing the uncertainty in organisations (according to SCHULTZE, 1998, SCHULTZE; STABELL, 2004, pp. 556-558).

Conversely to the functionalist, the interpretivist perspective emphasizes that reality (i.e. knowledge) is a result from human action and its creation of meaning; and it includes a "dynamic process of sense-making rather than being restricted solely to the assimilation of a body of facts" (MCADAM; MCCREDDY, 2000, p. 159). Here, knowledge is seen as a social practice of knowing and inseparable from action, being more as a process than as an object.

\footnotetext{
" Based on Burrel and Morgan's four sociological paradigms and different epistemologies adapted by Jashapara (2004, p. 41-44; Goles \& Hirschheim, 2000, pp. 253-254).
}

So, these different ways of understanding knowledge generates contradictions that weaken $\mathrm{KM}$, since the emphasis of discourse is on social and human activity of constructing, sharing and using knowledge; but the implementation is made by using methods that do not consider the interdependence, interrelationships and mutually constitutive interaction between human and knowledge (e.g., implementation of tools to promote the transformation of tacit to explicit knowledge).

When human action and influence are considered and a more interpretivist is adopted, other critical gaps are evidenced as risky to the KM fashion-setting probability. On this assumption, a [socio] constructivist perspective* brings out the following critical gaps which raise the chances of $\mathrm{KM}$ being a fashion:

(1) Semantic similarity between knowledge and information, thus equaling KM to IM.

According to the constructivist perspective in the Information Science field, information has a subjective approach and depends entirely on interpretations of a cognitive agent.

Particularly relevant and enlightening to the understanding of the semantic similarity between 'knowledge' and 'information' are the basic ideas (i.e., rooted on constructivism) of Professor Brenda Dervin and the 'Sense-Making' theoretical assumptions. According to Dervin (1980, p. 33, In: DERVIN et al. 2003), in the literature of social sciences, the concept of information is shifting from "observer constructions" (i.e., the information is a description of a reality separated from individuals) to "user constructions". In an information-as-user-construction model, the information is "created by human observers, is inherently a product of human self-interest, and can never be separated from the observers who created it" (DERVIN, 1989, p. 219, In: DERVIN et al. 2003).

Dervin (1999, pp. 148-61, In: DERVIN et al. 2003) also stated that information is constructed into the process of making sense of the world. This process is called 'sense-making', 'gap-bridging', 'informing' or 'knowing' (DERVIN, 2001, p. 239, 1991, p. 300, 1980, pp. 35-44, In: DERVIN et. al. 2003).

\footnotetext{
* Constructivism pertains to an interpretivist paradigm and considers that the social and organizational environments are settled by the understanding of the world, which is constructed by individuals in interaction with others (Jashapara, 2004, pp.43-45). In Information Science, constructivist ideas are commonly treated as "the cognitive viewpoint" an differs from cognitivism (Talja et al., 2005, p.79, 81).
} 
On another conceptualizations of making sense*, it is defined as a thinking process, as the interpretation of meaning, as comprehending, constructing meaning, "interacting in pursuit of mutual understanding and patterning” (WEICK, 1995, p. 6), it involves perceptions, thinking and feelings and it is considered as a process of learning (MARTON; BOOTH, 1997).

So, information is the sense made, is the product of 'informing', 'knowing' or of the 'sense-making', of an individual analysis and of a meaning creation. As stated by Dervin information is:

... a sense-made that stands as a bridge over a gap between one time-space moment and another and simultaneously between material and interpretative worlds (DERVIN, 1999, p. 150).

So, information is not just organized and contextualized facts as described in functionalist definitions. Beyond this, it is the sense or the meaning created as a result of a process of learning. Carefully analyzing, the used concept of 'knowledge' in KM (i.e. although vague and ambiguous) has the same meaning of 'information' in the constructivist perspective. According to Dervin (1998, p.36), the human sense-making study named 'Sense-Making"** "has made no distinction between knowledge and information". This study defines knowledge or information as being used for and as the product of the sense-making and unmaking process.

So, the semantic similarity between the constructivist perspective of 'information' concept and the used 'knowledge' concepts is noticeable. In sum, the discussion above demonstrates that this overlapping can evidence that KM can be just a new label for an approach that already exists (i.e., as IM).

\section{(2) The object / subject of management.}

Knowledge itself can not be managed since it can not be separated from human action. What $\mathrm{KM}$ is currently doing is more to information management than to knowledge management, since it focuses the efforts on the management of what can be codified, structured, processed; made tangible, captured and retrieved. KM manages in fact, representations or

\footnotetext{
"The meaning and the use of the concept sense-making on these other approaches are different form that made in the Sense-Making Methodology.
}

** Sense-Making is a metatheory (and methodology) which has roots in the constructivism. codifications about the knowledge constructed, but not the knowledge itself. Among the KM strategies we can identify that they treat only representations of knowledge like best practices sharing, knowledge maps and expertise yellow pages.

The constructivist perspective contests that knowledge can be managed as a separate object from the action of the individual; and states that knowledge is brought into operation by mindful action, being both the outcome of an action in context and also the input to it (SCHULTZE; STABELL, 2004, p. 558).

In sum, the object of management of the most of $\mathrm{KM}$ approaches is just knowledge that was codified, equalizing itself to IM approach. In relation to this, Al-Hawamdeh (2002) stated that IM handles knowledge that can be captured, processed and managed. As well, Hildreth and Kimble (2002, p. 1) also declared that the approach of capturing, codifying and storing, although presented in $\mathrm{KM}$, is in fact Information Resource Management (IRM) with a new label.

Polanyi (1966) and Kakabadse et al. (2001) explained that even if the knowledge is expressed in words or any other articulation form, it always relies on the knowledge that has been tacitly understood. It is also problematic if the 'tacit' knowledge is considered as the object of management of KM. This nature of knowledge is very difficult and almost impossible to be articulated, since it is very human and context sensitive. The tentative of making this knowledge represented leads to the loose of its meaning, once its context can not be structured. However, the non-articulation of 'tacit' knowledge does not mean that it can not be communicated by other forms (SPENDER, 1996, p.67).

So, one of the critical question that the constructivist view adds is the doubt about what $\mathrm{KM}$ manages in fact, since its object can not be structurable knowledge nor the 'tacit' knowledge.

The KM sustainability seems to be beyond the current phase of the criticisms and resides in the deepness of more conceptual and strategic questions.

In conclusion, the gaps identified by a constructivist perspective also put in risk the KM discourse and practice and can undermine multiple efforts in trying to make it a non-fashion approach. The gaps constitute, together with the dimensions identified in the criticisms (functionalist perspective), a set of critical questions that impact the conceptual foundations of KM. 
KM SUSTAINABILITY: PARADIGM SHIFT AND HUMAN ACTION CENTRED

The probability of KM to be just a new label for an existing approach is very high, considering all the issues pointed out by the criticisms; the issues outlined above and the current paradigm on which $\mathrm{KM}$ is based. This conclusion is founded on the main aspects discussed: the incongruence between paradigms applied on the conceptual and on the operative dimensions; the fact that $\mathrm{KM}$ is performing the same discourse and practice of IM (i.e., in both paradigm: functionalist and interpretivist); and the unclearness object of management and business problem addressed by the KM approach.

On top of all KM criticisms, the interpretivist concepts and the mechanistic implementation do not fit, because it is not possible to implement the relationship between human and knowledge, considering just a strategy of making knowledge explicit, and neglecting the power relations and the complex human behavior. So, the dominant functionalist perspective is not enough to support the dynamic relationship between human and knowledge; and so, misleading KM strategies and efforts. Treating knowledge as a thing that can be distributed by an intranet or stored in best practices databases is too simplistic for what knowledge can do for an organisation.

Following conclusion arguments, it is the fact that as the human action and a constructivist perspective are added to the fashion-setting probability which was stated by the criticisms, the scenario gets worse and strongly affected, showing the clear overlap with IM discourse and practice and the unclearness of KM management object. By a functionalist view, KM manages representations of knowledge, and by a constructivist view, knowledge is the same as information. Besides this, knowledge can not be managed, given it is highly personal and contextual.

So, KM should get to the next phase of 'transformation or decline' (i.e., as explained in umbrella concepts lifecycle - see appendix 1) (HIRSCH; LEVIN, 1999, p. 199). If KM does not succeed in overcoming fragmentation; in articulating a core and agreed theory; and identifying distinctly what is and what is not KM, the field faces a probable chance of returning to a new 'umbrella concept' (i.e., see appendix 1) or to the collapse of the KM concept (GREY; MEISTER, 2003, p. 262). In this context, a deep paradigm shift and a clear inclusion of human action in knowledge and KM understanding are largely demanded.
In conclusion, $\mathrm{KM}$ could move the needed changes towards being an enabler and a facilitator of 'knowing' and 'informing' processes. On this function, KM coordinates resources and competencies to support a favorable environment for the development of learning and of meaning construction and sharing. If the process of 'knowing' or 'informing' are facilitated, their products - knowledge, information, sense or meaning - can become more visible, observable and re-learnable. In addition to this, the business problem attended by KM should move, since it does not reside in the management of information overload, but in the creation of competencies to deal with this information overload, and of competencies to construct meaning, individual and collectively. As Spender (1996, p.64) states: "...on these days knowledge is less about truth and reason and more about the practice of intervening knowledgeably and purposefully in the world".

\section{Acknolwedgement}

The author is grateful for the funding given by the Brazilian Federal Government - Minister of Education and Culture (MEC) and the Coordenação de Aperfeiçoamento de Pessoal de Nível Superior (CAPES).

Artigo submetido em 18/08/2007 e aceito em 20/11/2007.

\section{REFERENCES}

ABRAHAMSON, E. Management fashion. The Academy of Management Review, v. 21, n. 1, p. 254-285, 1996.

; FAIRCHILD, G. Management fashion: lifecycles, triggers, and collective learning processes. Administrative Science Quarterly, v. 44, n. 4, p. 708 740, 1999.

; ROSENKOPF, L. Social network effects on the extent of innovation diffusion: a computer simulation. Organization Science, n. 8, p. 289-309, 1997.

AL-HAWAMDEH, S. Knowledge management: rethinking information management and facing the challenge of managing tacit knowledge. Information Research, v. 8, n. 1, 2002. Disponível em: <http:// InformationR.net/ir/8-1/paper143.html>. Acesso em: 13 out. 2005.

ALVESSON, M.; KÄRREMAN, D. Odd couple: making sense of the curious concept of knowledge management. Journal of Management Studies, v. 38, n. 7, p. 995-1018, 2001. 
BENDERS, J.; VEEN, K. V. What's in a fashion?: interpretative viability and management fashions. Organization, v. 8, p. 1, p. 33-53, 2001. Disponível em: $<$ http://org.sagepub.com/cgi/reprint/8/1/33 > Acesso em: 25 out. 2005.

DERVIN, B. Communication gaps and inequities: moving toward a reconceptualization. In: DERVIN, B.; FOREMAN-WERNET, L. (Ed.). Sense-making methodology reader: selected writings of Brenda Dervin. Cresskill: Hampton Press, 2003. p. 17-46.

Audience as listener and learner, teacher and confident: the sense-making approach. In: DERVIN, B.; FOREMAN-WERNET, L. (Ed.). Sense-making methodology reader: selected writings of Brenda Dervin. Cresskill: Hampton Press, 2003. p. $215-231$.

. Information as non-sense; information as sense: the communication technology connection. In: DERVIN, B.; FOREMAN-WERNET, L. (Ed.). Sensemaking methodology reader: selected writings of Brenda Dervin. Cresskill: Hampton Press, 2003. p. 293 -308.

. Sense-making theory and practice: an overview of user interests in knowledge seeking and use. Journal of Knowledge Management, v. 2, n. 2, p. 36-46, 1998.

. Sense-making's journey from metatheory to methodology to method: as example using information seeking and use as research focus. In: DERVIN, B.; FOREMAN-WERNET, L. (Ed.). Sensemaking methodology reader: selected writings of Brenda Dervin. Cresskill: Hampton Press, 2003. p.133-163.

. Sense-making methodology: communicating communicatively with campaign audiences. In: DERVIN, B.; FOREMAN-WERNET, L. (Ed.). Sense-making methodology reader: selected writings of Brenda Dervin. Cresskill: Hampton Press, 2003. p. 233-249.

GRAY, P. H.; MEISTER, D. B. Introduction: fragmentation and integration in knowledge management research. Information Technology $\mathbb{E}$ People, v. 16, n. 3, p. 259-265, 2003.

HIRSCH, P. M.; LEVIN, D. Z. Umbrella advocates versus validity police: a life-cycle model. Organization Science, v. 10, n. 2, p. 199-212, 1999.

JASHAPARA, A. Knowledge management: an integrated approach. HARLOW: Prentice-Hall, 2003.
KAKABADSE, N. K.; KOUZMIN, A.; KAKABADSE A. From tacit knowledge to knowledge management: leveraging invisible assets. Knowledge and Process Management, v. 8, n. 3, p. 137-154, 2001.

; KAKABADSE, A.; KOUZMIN, A. Reviewing the knowledge management literature: towards a taxonomy. Journal of Knowledge Management, v. 7, n. 4, p. 75-91, 2003. Disponível em: <http://www.emeraldinsight.com/10.1108/ 13673270310492967>. Acesso em: 11 nov. 2005.

KOENIG, M. E. Knowledge management lessons learned: the US perspective. Online Information 2004 Proceedings, Great Britain, n. 28, p. 37-43, 2004.

KM moves beyond the organization: the opportunity for librarians. In: WORLD LIBRARY AND INFORMATION CONGRESS: IFLA GENERAL CONFERENCE AND COUNCIL, 71., 2005, Oslo, Norway. Anais eletrônicos... Disponível em: < http:// www.ifla.org/IV/ifla71/papers/123e-Koenig.pdf $>$. Acesso em: 25 mar. 2006.

MARTENSSON, M. A critical review of knowledge management as a management tool. Journal of Knowledge Management, v. 4, n. 3, p. 204-216, 2000.

MCADAM, R.; MCCREEDY, S. A critique of knowledge management: using a social constructionist model. New Technology, Work and Employment, v. 15, n. 2, p. $155-168,2000$.

METAXIOTIS, K.; ERGAZAKIS, K.; PSARRAS, J. Exploring the world of knowledge management: agreements and disagreements in the academic / practitioner community. Journal of Knowledge Management, v. 9, p. 2, p. 6-18, 2005.

MILLER, D.; HARTWICK, J.; MILLER, I. How to detect a management fad - and distinguish it from a classic. Business Horizons, v.47, n.4, p. 7-16, 2004.

PONZI, L.; KOENIG, M. Knowledge management: another management fad?. Information Research, v. 8, p. 1, 2002. Paper n. 145. Disponível em: <http:// InformationR.net/ir/8-1/paper145.html $>$. Acesso em: 18 nov. 2005.

POLANYI, M. The tacit dimension. London: DOUBLEDAY \& CO, 1966.

SCARBROUGH, H.; ROBERTSON, M.; SWAN, J. Professional media and management fashion: the case 
of knowledge management. Scandinavian Journal of Management, v. 21, n. 2, p. 197-208, 2005.

; SWAN, J. Explaining the diffusion of knowledge management: the role of fashion. British Journal of Management, v. 12, n. 1, p. 3-12, 2001.

SCHULTZE, U. Investigating the contradictions in knowledge management. In: IFIP WORKING GROUPS 8.2 AND 8.6 JOINT WORKING CONFERENCE ON INFORMATION SYSTEMS: CURRENT ISSUES AND FUTURE CHANGES, 1998, Helsinki, Finland. Electronic proceedings... Disponível em: $<$ http:// citeseer.ist.psu.edu/cache/papers/cs/12916/ http:zSzzSzwww.bi.nozSzdep2zSzinfomgtzSzwg8286zSzproceedingszSzschultze.pdf/schultze98investigatin g.pdf>. Acesso em: 12 nov. 2005.

; STABELL, C. Knowing what you don't know?: discourses and contradictions in knowledge management research. Journal of Management Studies, v. 41, n. 4, p. 549-573, 2004.

SPENDER, J. C. Organizational knowledge, learning and memory: three concepts in search of a theory. Journal of Organizational Change Management, v. 9, n. 1, p. 63-78, 1996. Disponível em: <http://64.233.183.104/ search?q= cache:A8HJzMnhDO8J:www.aradolibrary.org.eg/ organizational $\% 25201$ earning $\% 2520 \mathrm{pdf} /$ p63_s.pdf $++\% 22$ organizational + knowledge, + learning + and + memory\%22\&hl $=$ pt $-B R>$. Acesso em: 09 nov. 2005.

STREATFIELD, D.; WILSON, T. D. Deconstructing knowledge management. Aslib Proceedings, v. 51, n. 3, p. 67-72, 1999.

SVEIBY, K. Frequently asked questions-Why should knowledge be managed?. Disponível em: <http://www.sveiby.com/ faq.html\#Whyshould >. Acesso em: 14 nov. 2005.

SWAN, J.; NEWELL, S.; ROBERTSON, M. Knowledge management: when will people management enter the debate?, 2000. In: ANNUAL HAWAII INTERNATIONAL CONFERENCE ON SYSTEM SCIENCES, 33., 2005, Maui. Electronic proceedings... [S.1.]: IEEE Computer Society Press. Disponível em: <http:// csdl2.computer.org/comp/proceedings/hicss/2000/ 0493/03/04933026.pdf>. Acesso em: 20 nov. 2005.

TALJA, S.; TUOMINEN, K.; SAVOLAINEN, R. Isms in information science: constructivism, collectivism and constructionism. Journal of Documentation, v. 61, n. 1, p. 79-101, 2005.

THE KPMG CONSULTING. Knowledge management research report 2000. 2000. Disponível em: < http:// www.insite.cz/data/kpmg_km_report2000.pdf $>$. Acesso em: 17 nov. 2005.

TSOUKAS, H.; VLADIMIROU, E. What is Organizational Knowledge?. Journal of Management Studies, v. 38, n. 7, p. 973-993, 2001.

WEICK, K. E. Sensemaking in organizations. THOUSAND OAKS: Sage Publications, 1995.

WILLIAM, R. Management fashions and fads: understanding the role of consultants and managers in the evolution of ideas. Management decision, v. 42, n. 6, p. 769-780, 2004.

WILSON, T. D. The nonsense of knowledge management. Information Research, v. 8, n. 1, 2002. Paper n. 144. Disponível em: <http://InformationR.net/ir/8-1/ paper144.html>. Acesso em: 10 nov. 2005.

\section{APÊNDICE}

The 'umbrella construct' was proposed by Hirsch \& Levin (1999). An 'umbrella construct' is "a broad concept or idea used loosely to encompass and account for a set of diverse phenomena". Its construction follow a life-cycle constituted by three phases (fig.6) and, KM seems to be in the phase of 'tidying up with typologies', walking to making the construct more coherent (override the challenges), settle an agreement over the definitions (permanent issue) or requesting the end of its activity (construct collapse) Hirsch \& Levin (1999, p. 200-205).

FIGURE 6

Umbrella constructs process proposed by Hirsch

\& Levin (1999, p. 204-205).

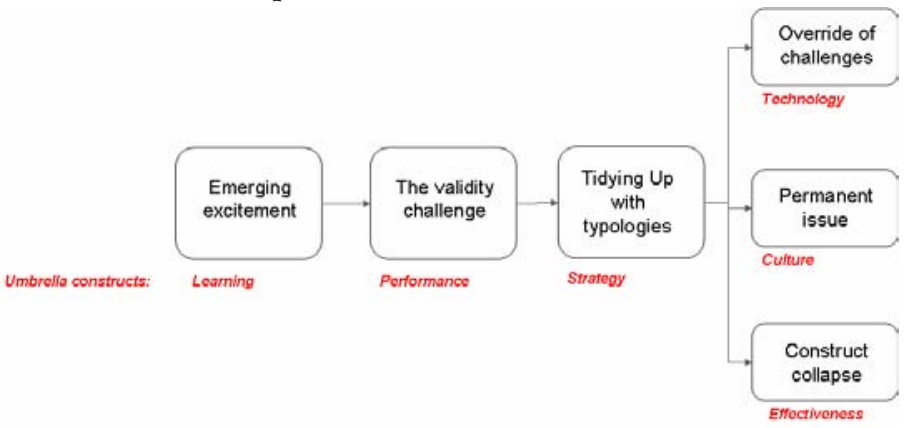

